\title{
Óútskýrður skyndidauði
}

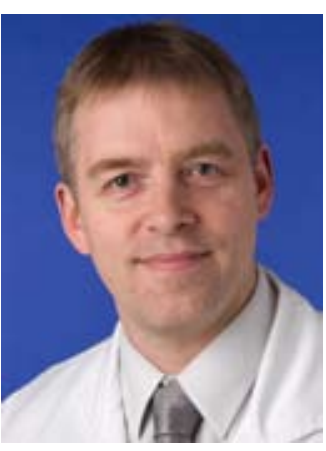

Davíð O. Arnar

davidar@landspitali.is

Höfundur er sérfræđingur í lyflækningum og hjartasjúkdómum og starfar á Landspítala.

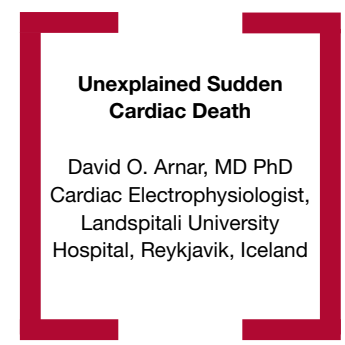

Af og til flytja fjölmiðlar fréttir af ungu fólki sem hefur dáið skyndilega. Slíkir atburðir vekja óhug par sem oftast er um að ræða fólk í blóma lífsins sem áður virtist heilsuhraust. Skyndidauði er nokkuð algengur á Vesturlöndum og er að stærstum hluta vegna hjartastopps. Flest tilfelli skyndidauða, sér í lagi hjá einstaklingum yfir fimmtugt, tengjast kransæðasjúkdómi og/eða skerðingu á útfallsbroti vinstri slegils. Rannsóknir hafa sýnt fram á að hjá pessum aldurshópi eru áhættupættir skyndidauða hinir sömu og fyrir kransæðasjúkdóm. ${ }^{1}$ Í um 10\% tilfella finnst ekki skýring á pví hvað olli hjartastoppinu, jafnvel pó krufning sé framkvæmd. ${ }^{2}$

Hjá yngri einstaklingum er kransæðasjúkdómur ekki jafnveigamikil orsök skyndidauða og hjá peim sem eldri eru. Sjaldgæfari vandamál eins og hjartavöðvasjúkdómar og frumkomnar raflífeðlisfræðilegar raskanir eru algengari sem orsakavaldur skyndidauða meðal peirra yngri. Ástæða hjartastopps getur verið óutskýrð í allt að priðjungi tilfella hjá ungum einstaklingum. ${ }^{3}$

Nýlega voru birtar niðurstöður rannsóknar á hópi ungra einstaklinga (meðalaldur 43 ár) sem höfðu verið endurlífgaðir eftir hjartastopp. ${ }^{4}$ Orsök pess var ópekkt prátt fyrir hefðbundnar rannsóknir eins og hjartalínurit, ómskoðun af hjarta og hjartapræðingu. Pessir sjúklingar voru skoðaðir á enn ítarlegri hátt og meðal annars framkvæmd segulómun af hjarta, áreynslupróf, sýnataka úr hjartavöðva og lyfjaörvun með adrenalíni, prókaínamíði og ergónóvíni til að reyna að framkalla dulda raflífeðlisfræðilega röskun og kransæðaherping. Erfðafræðileg prófun var aukinheldur framkvæmd ef niðurstöður klínískra rannsókna gáfu tilefni til. Líkleg skýring fannst hjá rúmlega helmingi hópsins með pessum ítarlegu viðbótarrannsóknum. Hjá tveimur priðju fannst raflífeðlisfræðileg röskun sem ekki hafði komið fram á hjartalínuriti. Til peirra teljast vandamál eins og heilkenni lengds QT-bils, katekólamín orsakaður sleglahraðtaktur (catecholaminergic ventricular tachycardia) og Brugada-heilkenni. Hjá priðjungi komu í ljós sjúkdómar eins og hjartavöðvabólga og rangvöxtur í hægri slegli. Hjá nokkrum til viðbótar tókst að framkalla kransæðaherping en endurflæðistakttruflun frá sleglum getur komið fram pegar herpingnum sleppir og orsakað hjartastopp. Auk ofangreindra ástæðna eru ósamhverf hjartavöðvapykknun og meðfædd frávik á legu kransæða pekktar orsakir skyndidauða, ekki síst hjá yngra fólki, en pessi vandamál eru oftast greind með hjartalínuriti, ómskoðun, hjartapræðingu eða við krufningu.
Heilkenni lengds QT-bils, katekólamín orsakaður sleglahraðtaktur og Brugada-heilkenni eru arfgengir sjúkdómar og eru nokkrar stökkbreytingar og erfðabreytileikar pekktir sem geta valdið peim. Hins vegar finnast pessar stökkbreytingar og erfðabreytileikar aðeins í hluta peirra sem greinast með pessa sjúkdóma. Páttur erfðabreytileika í raflífeðlisfræðilegum röskunum hefur pví ekki verið að fullu metinn. Ummerki um pessa sjúkdóma koma ekki alltaf fram á hjartalínuriti og klínísk greining getur pannig verið vandasöm. Vísbendingar um pessa sjúkdóma finnast ekki við krufningu peirra sem deyja skyndidauða.

Í vissum tilfellum geta erfðafræðileg próf hjálpað til við greiningu sjúkdóma eins og heilkennis lengds QT-bils og katekólamín orsakaðs sleglahraðtakts. Pessi próf er mögulegt að framkvæma á lífsýnum eftir andlát og hefur sú nálgun verið kölluð sameindaerfðafræðileg krufning (molecular autopsy). ${ }^{2,3}$ Vonir standa til pess að pessi próf geti hjálpað til við frekari greiningu á orsökum óútskýrðs skyndidauða. Nákvæm greining á orsök skyndidauða getur verið mjög mikilvæg par sem hún getur í vissum tilfellum leitt til fyrirbyggjandi meðferðar hjá nákomnum ættingjum ýmist með lyfjum eða bjargráð. Pessi erfðafræðilegu próf eru pó mörg hver kostnaðarsöm og á pessu stigi er ekki ljóst hvernig hagkvæmast er að beita peim. ${ }^{2}$ Fyrirliggjandi rannsóknarniðurstöður styðja pó að notkun erfðafræðilegra prófa ætti fyrst og fremst að byggja á klínískum grunsemdum og peim upplýsingum sem til eru um svipgerð sjúklings. ${ }^{2,4}$

Peir sem lifa af hjartastopp ættu að undirgangast ítarlega klíníska skoðun til greiningar á mögulegri orsök. Hjá nánum ættingjum peirra sem deyja skyndidauða er við hæfi að framkvæma klínískt mat, skoðun með hjartalínuriti og frekari rannsóknir í völdum tilfellum, sér í lagi ef grunur er um arfgenga orsök. Notkun erfðafræðilegra prófa til greiningar á raflífeðlisfræðilegum röskunum er lofandi en á pessu stigi er óvíst hvernig best er að beita peim.

\section{Heimildir}

1. Porgeirsson G, Porgeirsson G, Sigvaldason H, Witteman J. Risk factors for out-of-hospital cardiac arrest: the Reykjavik study. Eur Heart J 2005; 26: 1499-505.

2. Priori SG. Unexplained sudden cardiac death - back to clinical evaluation. Nat Rev Cardiol 2009; 6: 678-9.

3. Ackerman MJ, Tester DJ, Driscoll DJ. Molecular autopsy of sudden unexplained death in the young. Am J Forensic Med Pathol 2001; 22: 105-11.

4. Krahn AD, Healy JS, Chauhan V, et al. Systematic assessment of patients with unexplained cardiac arrest. Circulation 2009; 120: 278-85. 